\title{
Recycling the Sacred: Material Culture and Cultural Memory after the English Reformation
}

\author{
AleXANDRA Walsham
}

This article examines medieval liturgical artifacts that survived the English Reformation by being converted to alternative religious and secular purposes. Exploiting both textual and material evidence, it explores how sacred objects were adapted and altered for a range of domestic and ecclesiastical uses, together with the underlying theological assumptions about adiaphora or "things indifferent" that legitimized such acts of "recycling." These are situated on a continuum with iconoclasm and approached as dynamic and cyclic processes that offer insight into how Protestantism reconfigured traditions of commemoration and patterns of remembrance. Simultaneously, it recognizes their role in resisting religious change and in preserving tangible traces of the Catholic past, showing how converted objects served to perpetuate and complicate social and cultural memory. The final section investigates the ambiguous longer-term legacies of this reform strategy by probing the significance of growing concerns about the sin of 'sacrilege' committed by those who had profaned holy things.

$\mathrm{I}$ $\mathrm{N}$ his Church History of Britain (1655), the royalist divine Thomas Fuller painted an evocative picture of the impact of the Protestant Reformation on the material culture of medieval English Catholicism. In a compelling passage regarding the reforms carried out during the reign of Edward VI, he described how "private mens halls were hung with Altar-cloathes; their tables and beds, covered with copes, instead of carpets, and coverlets. Many drank at their daily meals in chalices; and no wonder, if in proportion it came to the share of their horses to be watered in rich coffins of marble." Alive to the parallels with the tumultuous events that took place during the civil wars of his own time, he reflected ruefully on developments that had sanctioned the removal of many sacred objects from consecrated buildings and encouraged their redeployment for a range of profane purposes. His

This essay arises from research undertaken in connection with the collaborative project "Remembering the Reformation," funded by the UK Arts and Humanities Research Council (https://rememberingthereformation.org.uk/). I am grateful to Bronwyn Wallace for her very helpful advice on an earlier draft and to audiences in Edinburgh, London, Columbus, and Vancouver for their stimulating comments. I also acknowledge the support of the Leverhulme Trust.

${ }^{1}$ Thomas Fuller, The Church-history of Britain; from the Birth of Jesus Christ, untill the Year M. DC.XLVIII (London, 1655), 417.

Alexandra Walsham is Professor of Modern History at the University of Cambridge. 
comments illuminate the role that the Reformation played in altering the physical fabric of both religious worship and everyday life, as well as in transforming the landscape of social memory itself. This article seeks to place these intriguing processes under the spotlight.

Over the last few decades, historians have lavished attention on the victims of the violent spasms of iconoclasm that accompanied the protracted religious revolution of the sixteenth and seventeenth centuries: the defaced rood screens, mutilated statues, and ruined monasteries that stand as poignant relics of a religious past that zealous Protestants, driven by intense anxiety about the sin of idolatry, were intent upon consigning to oblivion. ${ }^{2}$ Correcting the lingering fallacy that the Reformation was inherently antagonistic to Christian materiality, ${ }^{3}$ they have also begun to investigate the newly manufactured objects that filled Protestant churches and homes: the pulpits, pews, fonts, and funeral monuments that embodied the theology of the Word and the schemes of interior decoration and furnishing-from earthenware pots, plaster ceilings, and stove tiles to tapestries, chimney breasts, and firebacks - that advanced its moral and spiritual priorities and functioned as badges of confessional belonging. ${ }^{4}$ By contrast, medieval religious artifacts that survived the turbulent changes of the period by being adapted for alternative use have been comparatively neglected in recent scholarship.

\footnotetext{
${ }^{2}$ See esp. Margaret Aston, England's Iconoclasts, vol. 1 Laws against Images (Oxford: Clarendon, 1988); Aston, Broken Idols of the English Reformation (Cambridge: Cambridge University Press, 2016); Julie Spraggon, Puritan Iconoclasm during the English Civil War (Woodbridge: Boydell, 2003); John Walter, “'Abolishing Superstition with Sedition'? The Politics of Popular Iconoclasm in England 1640-1642," Past and Present 183 (May 2004): 79123; and Tabitha Barber and Stacy Boldrick, eds., Art Under Attack: Histories of British Iconoclasm (London: Tate, 2013).

${ }^{3}$ See Dick Houtman and Birgit Meyer, eds., introduction to Things: Religion and the Question of Materiality, ed. Houtman and Meyer (New York: Fordham University Press, 2012), 1-23.

${ }^{4}$ See Andrew Morrall, "Protestant Pots: Morality and Social Ritual in the Early Modern Home," Journal of Design History 15, no. 4 (2002): 263-273; David Gaimster, "Pots, Prints and Propaganda: Changing Mentalities in the Domestic Sphere 1480-1580," in The Archaeology of Reformation 1480-1580, ed. Gaimster and Roberta Gilchrist (Leeds: Maney, 2003), 122-144; Ulinka Rublack, Reformation Europe (Cambridge: Cambridge University Press, 2005), chap. 4; Tara Hamling and Richard L. Williams, eds., Art Re-formed: Re-assessing the Impact of the Reformation on the Visual Arts (Newcastle: Cambridge Scholars, 2007); Tara Hamling, Decorating the Godly Household: Religious Art in Post-Reformation Britain (New Haven, Conn.: Yale University Press, 2010); Andrew Spicer, Calvinist Churches in Early Modern Europe (Manchester: Manchester University Press, 2007); Spicer, ed., Lutheran Churches in Early Modern Europe (Farnham: Ashgate, 2012); Spicer, "The Material Culture of Early Modern Churches," in The Routledge Handbook of Material Culture in Early Modern Europe, ed. Catherine Richardson, Tara Hamling, and David Gaimster (London: Routledge, 2017), 8297; and Alexandra Walsham, "Domesticating the Reformation: Material Culture, Memory and Confessional Identity in Early Modern England," Renaissance Quarterly 69, no. 2 (2016): 566616. For an overview of recent work, see Bridget Heal, "Visual and Material Culture," in The Oxford Handbook of the Protestant Reformation, ed. Ulinka Rublack (Oxford: Oxford University Press, 2016), 601-620.
} 
The current piece of vocabulary that best describes this process, recycling, had not yet been invented in the sixteenth century. The word, as both noun and verb, was first coined in the 1920s in connection with industrial processes and subsequently taken up by the environmental movement as a response to growing concerns about the wastefulness and pollution engendered by modern capitalist consumerism. ${ }^{5}$ Its closest equivalent in the early modern era was "conversion," a term that had both literal and figurative meanings and that applied to people and objects as well as to the mind, emotions, and the soul. From at least the fourteenth century, it was deployed to denote a turn from sinful or irreligious life to godliness, but also to refer to the act of diverting something from its original use or purpose and changing its character, function, and form. ${ }^{6}$ Describing the inner and outer regeneration that was the chief objective of the Reformation, it serves as a fruitful paradigm for probing how religious acculturation occurred in the context of a state-led and institutional Reformation that was animated and complicated by popular impulses that sprang up from below. ${ }^{7}$

Recycling in its more literal sense has been less scrutinized. In a pioneering essay entitled "Swords into Plougshares" published in 1985, Donald Woodward delineated its unrecognized role in a pre-industrial English economy characterized by endemic poverty and unemployment. His interest in the fate of religious objects rendered redundant by Protestant reform was one aspect of a wider attempt to assess the contribution that recycling made to national welfare. ${ }^{8}$ It is to archaeologists, however, that we owe most of our knowledge of how dissolved monasteries and chantries were repurposed as domestic dwellings in the wake of the Reformation and plundered as quarries for stone and lead. They have also led the way in assessing how

\footnotetext{
${ }^{5}$ Oxford English Dictionary Online, s.vv. "recycle (v.)," "recycling (n.)," accessed 26 July 2017, http://www.oed.com/.

${ }^{6}$ Oxford English Dictionary Online, s.vv. "convert (v.)," "conversion (n.)," accessed 26 July 2017, http://www.oed.com/. Another word used to describe these processes, particularly in relation to monastic buildings, was "translation." As Jennifer Summit has commented, this served to downplay the violence entailed in the suppressions of the 1530s: "Leland's 'Itinerary' and the Remains of the Medieval Past," in Reading the Medieval in Early Modern England, ed. Gordon McMullan and David Matthews (Cambridge: Cambridge University Press, 2007), 161.

${ }^{7}$ For some stimulating discussions of conversion, see Michael Questier, Conversion, Politics and Religion in England, 1580-1625 (Cambridge: Cambridge University Press, 1996); Kenneth Mills and Anthony Grafton, eds., Conversion: Old Worlds and New (Rochester, N.Y.: University of Rochester Press, 2003); Peter Mazur and Abigail Shinn, eds., "Conversion Narratives in the Early Modern World," special issue, Journal of Early Modern History 17, no. 5-6 (2013); and Simon Ditchfield and Helen Smith, eds., Conversions: Gender and Religious Change in Early Modern Europe (Manchester: Manchester University Press, 2017).

${ }^{8}$ Donald Woodward, “'Swords into Ploughshares': Recycling in Pre-Industrial England," Economic History Review, 2nd ser., 38, no. 2 (May 1985): 175-191. See also Ariane Fennetaux, Amélie Junqua, and Sophie Vasset, eds., The Afterlife of Used Things: Recycling in the Long Eighteenth Century (New York: Routledge, 2015).
} 
other moveable goods and monuments were recast to enable them to navigate successive phases of religious upheaval, becoming palimpsests of what Maurice Howard has termed "the constant rethinking of the permissible."

Here I set aside the temptation to import them into tired debates about the "success" or "failure" of the Reformation and its alleged role in "desacralization" and "secularization," in favor of exploring what they reveal about memory and its transmutation in the two centuries following the Henrician break with Rome. Approaching such objects not as inert emblems but as active agents and engines of cultural change, I treat the adaptation of Catholic material culture for reformed use as a dynamic and cyclical process that offers insight into how Protestantism reconfigured traditions of commemoration and patterns of remembrance. Remodeled and recontextualized objects are analyzed as lieux de mémoire that facilitated forms of both remembering and forgetting: they effaced a past that they simultaneously continued to make present. ${ }^{10}$ They did so in ways that tested and problematized the Reformation, even as they helped to cement it.

Taking inspiration from recent theoretical work by Arjun Appadurai, Igor Kopytoff, and others on the social life of things and the cultural biography of objects, ${ }^{11}$ this article proceeds from the assumption that human and object histories are inextricably intertwined and that memory is a bodily and sensory process as well as a cognitive one, involving eyes and hands as well as the mind. The technical term archaeologists use to describe the tactile and

\footnotetext{
${ }^{9}$ Quotation from Maurice Howard, "Art Re-formed: Spiritual Revolution, Spatial Re-location," in Art Re-formed, ed. Hamling and Williams, 291. For some recent work in this area, see Gaimster and Gilchrist, The Archaeology of Reformation 1480-1580, esp. Sarah Tarlow, "Reformation and Transformation: What Happened to Catholic Things in a Protestant World?," 108-121; and Nicholas Doggett, Patterns of Re-Use: The Transformation of Former Monastic Buildings in Post-Dissolution Hertfordshire, 1540-1600, British Series 331 (Oxford: British Archaeological Reports, 2002).

${ }^{10}$ Pierre Nora, "Between Memory and History: Les Lieux de Mémoire," in "Memory and Counter-Memory," ed. Natalie Zemon Davis and Randolph Starn, special issue, Representations 26 (Spring 1989): 7-24. See also Jaś Elner, "Iconoclasm and the Preservation of Memory," in Monuments and Memory, Made and Unmade, ed. Robert S. Nelson and Margaret Olin (Chicago: University of Chicago Press, 2003), 209-231; and Ann Stahl, "Material Histories," in The Oxford Handbook of Material Culture Studies, ed. Dan Hicks and Mary C. Beaudry (Oxford: Oxford University Press, 2010), 156-172.

${ }^{11}$ Arjun Appadurai, ed., The Social Life of Things: Commodities in Cultural Perspective (Cambridge: Cambridge University Press, 1986); and Igor Kopytoff, "The Cultural Biography of Things: Commoditization as Process," in The Social Life of Things, ed. Appadurai, 64-91. See also Chris Gosden and Yvonne Marshall, "The Cultural Biography of Objects," World Archaeology 31, no. 2 (October 1999): 169-178; Roberta Olson, Patricia Reilly, and Rupert Shepherd, eds., "The Biography of the Object in Late Medieval and Renaissance Italy," special issue, Renaissance Studies 19, no. 5 (November 2005); and Tara Hamling and Catherine Richardson, ed., Everyday Objects: Medieval and Early Modern Material Culture and its Meanings (Farnham: Ashgate, 2010).
} 
somatic aspects of remembering is "haptic."12 Exploiting a combination of documentary, material, and archaeological evidence, the discussion that follows focuses on what Victorian and Edwardian antiquarians called "church furniture": on fixed and portable objects that played a key part in the medieval liturgy and their post-Reformation reincarnations. ${ }^{13}$ Although, paradoxically, their adaptation was a mode of preservation, deciphering the sixteenth- and seventeenth-century afterlives of these items is frustrated by the problem of survival: by the randomness of what has been deliberately discarded or accidentally lost in subsequent ages. It is also complicated by the additional, often deceptive, and ambiguous layers of meaning they acquire each time they are remade.

\section{The Stripping of the Altars}

Like most of its cousins on the continent, the English Reformation entailed balancing the drive for purification with a dose of pragmatism. The Tudor state had neither the resources nor the inclination to remove all the physical structures constructed by the medieval Church and to engage in the wholesale destruction of their fabric and furnishings. The most visible symbols of Roman Catholic belief fell under the royal axe in the 1530s and 1540s. Justified by polemic that denounced them as dens of vice and corruption and that undercut the entire concept of meritorious living in the isolation of a cloister, the dissolution of the monasteries provided the crown with an excuse to ruthlessly appropriate their wealth. ${ }^{14}$ The Edwardian attack on the second plank of the theology of good works and intercessory prayer, the chantries, was underpinned by reformed repudiation of the precept that the living and

\footnotetext{
${ }^{12}$ Alan Radley, "Artefacts, Memory and a Sense of the Past," in Collective Remembering, ed. David Middleton and Derek Edwards (London: Sage, 1990), 46-59; Leora Auslander, "Beyond Words," American Historical Review 110, no. 4 (October 2005): 1015-1045; and Andrew Jones, Memory and Material Culture (Cambridge: Cambridge University Press, 2007). On the haptic, see Caroline Bynum, "Are Things 'Indifferent'? How Objects Change our Understanding of Religious History,” German History 34, no. 1 (March 2016): 92.

${ }^{13}$ Edward Peacock, ed., English Church Furniture, Ornaments and Decorations, at the Period of the Reformation: As Exhibited in a List of the Goods Destroyed in Certain Lincolnshire Churches, AD 1566 (London: Hotten, 1866); and J. Charles Cox and Alfred Harvey, English Church Furniture (London: Methuen, 1907; Wakefield: E. P., 1973) (citations refer to the E. P. edition).

${ }^{14} \mathrm{~A}$ new account of the dissolution is overdue. In the interim, see David Knowles, Bare Ruined Choirs: The Dissolution of the English Monasteries (Cambridge: Cambridge University Press, 1976); and G. W. Bernard, "The Dissolution of the Monasteries," History 96, no. 324 (October 2011): 390-409. Harriet Lyon's PhD dissertation ("The Afterlives of the Dissolution of the Monasteries in England, c. 1533-1700" [University of Cambridge, forthcoming]) discusses the neglected theme of converted monastic buildings. For a study of these processes in the German Reformation, see Christopher Ocker, Church Robbers and Reformers in Germany, 1525-1547: Confiscation and Religious Purpose in the Holy Roman Empire (Brill: Leiden, 2006).
} 
the dead could assist each other in earning a place in paradise. ${ }^{15}$ In demolishing institutions that embodied the disputed doctrine of purgatory, Protestants launched a profound assault upon the machinery of salvific remembering.

Parish churches themselves were spared the fate of the abbeys, priories, and chantries, despite the calls of religious radicals such as the separatist Henry Barrow and John Smyth for these buildings to be made "desolate" and "laid on heapes" like their "younger sisters" because they could "never be clensed" of the "fretting leprosie" of popery. ${ }^{16}$ Instead, they expelled the "monuments of superstition" that operated as stumbling blocks to the weaker brethren and stripped away the sumptuous interiors that were thought to provoke what the Homily on Idolatry termed "spiritual fornication." 17 They prioritized restoring the simplicity of apostolic practice and converting and equipping churches for Protestant services. Relics, shrines, and statues of the Virgin Mary and saints were removed, followed by altars and rood lofts. But other remnants of Catholic worship, including stained glass windows, were simply left to decay "little by little." As William Harrison later commented in his Description of England (1587), this was "for want of sufficient store of new stuffe, and by reason of extreame charge that should grow by the alteration of the same into white panes throughout the realme": the cost of reglazing them all at once would have been prohibitive. ${ }^{18}$ Censored of their incriminating indulgences, many funeral monuments and brasses were also permitted to remain: indeed, a proclamation of 1560 drew a line between idolatry and legitimate commemoration by condemning those who "barbarously" attacked memorials set up in honor of the eminent dead and not "to nourish any kind of superstition." "I In some surviving examples, such as a brass to John Smythe at the church of Stutton in Suffolk dated 1534 , the prayer clauses have been carefully scratched out. ${ }^{20}$

\footnotetext{
${ }^{15}$ On the dissolution of the chantries, see Alan Kreider, English Chantries: The Road to Dissolution (Cambridge, Mass.: Harvard University Press, 1979); and Ethan H. Shagan, Popular Politics and the English Reformation (Cambridge: Cambridge University Press, 2003), chap. 7. On the demise of purgatory, see Peter Marshall, Beliefs and the Dead in Reformation England (Oxford: Oxford University Press, 2002), esp. chaps. 1-3.

${ }^{16}$ Henry Barrow, A Briefe Discoverie of the False Church ([Dort?], 1590), 132. John Smyth predicted that "idol temples" would be converted, like the monasteries themselves, into "barnes, stables, swinestyes, [and] jakes . . . when the howre of their visitation shal come": Parallels, censures, observations . . ([Middelburg?], 1609), 121-122. See also Aston, Broken Idols, 88-89.

17"An Homilie against perill of idolatrie, and superfluous decking of churches," in Certaine Sermons or Homilies Appointed to be Read in Churches (London, 1623), 49, 61.

${ }^{18}$ William Harrison, The Description of England, in The First and Second Volumes of Chronicles (London, 1587), bk. 2, chap. 1, p. 138.

${ }^{19}$ Paul L. Hughes and James F. Larkin, eds., Tudor Royal Proclamations, 3 vols. (New Haven, Conn.: Yale University Press, 1964-1969), 2:146-147.

${ }^{20}$ See Trevor Cooper, ed., The Journal of William Dowsing: Iconoclasm in East Anglia during the English Civil War (Woodbridge: Boydell, 2001), plate 37b, and see pp. 103, 105. It is possible that this defacement was carried out during the Civil War.
} 
Parish churches did not, however, escape the rapaciousness of the early modern state. Openly admitting its urgent need for "a masse of money," the Edwardian regime made objects that liturgical reform had now rendered obsolete the subject of an extraordinary campaign of expropriation that culminated in 1552. It ordered inventories to be compiled of the silver and gilt chalices and other vessels, candlesticks, ornaments, copes, cloths, and bells possessed by every parish, together with estimates of their monetary value. Items that had been stolen, embezzled, alienated, or sold off by the consent of the parish since the accession of the young king were to be listed in an appendix. All but the bare minimum needed to celebrate the reformed Eucharist was sent to the Jewel House at the Tower of London to be melted down or auctioned locally to the highest bidder. ${ }^{21}$

Under Elizabeth, the process of purging churches was renewed to reverse the effects of Mary I's Counter Reformation, when the prohibited paraphernalia of the mass was partially restored. New questionnaires regarding superfluous and "superstitious" articles of ecclesiastical furniture left over from the Catholic era were issued. In part catalogues of sacred objects that had already been defaced and/or put to alternative use, these documents also functioned as promissory notes: as written undertakings that the churchwardens would cleanse their churches of remaining vestiges of popery. ${ }^{22}$

These processes must be seen in the context of a parallel set of manoeuvres that was taking place in the realm of Protestant polemic. One of the tactics the reformers deployed to discredit traditional assumptions about hallowed objects was to reduce them rhetorically from precious treasures to worthless rubbish. ${ }^{23}$ Lollards laid the foundations in insisting that images were not touchstones and conduits of divine power but mere "stocks and stones," and the theme was emphatically taken up by evangelicals in the $1530 \mathrm{~s}, 1540 \mathrm{~s}$, and $1550 \mathrm{~s} .{ }^{24} \mathrm{~A}$ disparaging language of "trumpery," "trash," "trifles," "toys," "paltry," "pelfry," "baggage," and "gear" suffuses the Edwardian and Elizabethan

\footnotetext{
${ }^{21}$ John Roche Dasent, ed., Acts of the Privy Council (London: Her Majesty's Stationery Office, 1891), 3:228. Eamon Duffy has explored this process with different objectives in "The End of it All: The Material Culture of the Late Medieval Parish and the 1552 Inventories of Church Goods," in Saints, Sacrilege and Sedition: Religion and Conflict in the Tudor Reformations (London: Bloomsbury, 2012), 109-129.

${ }^{22}$ For one surviving set of returns from Lincolnshire, see Peacock, English Church Furniture. For a discussion of these returns, which anticipates some of the points made below, see Aston, Broken Idols, 164-183.

${ }^{23}$ On this theme, see my "The Pope's Merchandise and the Jesuits' Trumpery: Catholic Relics and Protestant Polemic in Post-Reformation England," in Religion, the Supernatural and Visual Culture in Early Modern Europe: An Album Amicorum for Charles Zika, ed. Jennifer Spinks and Dagmar Eichberger (Brill: Leiden, 2015), 370-409.

${ }^{24}$ Aston, England's Iconoclasts, chap. 4.
} 
inventories and other official documents. ${ }^{25}$ Nowhere did this demystifying discourse find more powerful expression than in Jean Calvin's corrosive satire on the cult of relics, a text that took the form of a mock-register and dismissed most of them as fake and counterfeit. Manufactured by the clergy to raise money and to keep the laity in awe and subjugation, they were not sublime and priceless, but rather a form of cheap papal "merchandise." Translated into English in 1561, this tract set the tone for a succession of pamphlets and prints that equated sacred Catholic objects with economic commodities of little monetary value. ${ }^{26}$ In a well-known woodcut in John Foxe's Actes and Monuments, the papists are depicted salvaging church furnishings from purified churches, "packing away their paltry," and shipping it overseas. ${ }^{27}$ The vocabulary of waste with which such texts and images were saturated not merely helped to justify casting such things onto bonfires of vanities; it also made them available for recycling.

The strategy of converting church goods and furnishings to other uses was underpinned by the principle that such items were not in and of themselves evil. Ontologically speaking, there was nothing inherently wrong with these objects. The raw materials of which they were made-wood, stone, metal, and textiles - were part of God's creation. Idolatry was incidental rather than integral to them. ${ }^{28}$ They fell into the category of adiaphora (or "things indifferent"), which Christians had the liberty to utilize, providing that they did so in the interests of order and the edification of their neighbors. ${ }^{29}$ Although they were tainted by their prior association with popish rites, only a small minority of English Protestants thought that they were so defiled and compromised by the impurity of their origins as to necessitate their total annihilation. ${ }^{30}$ Redeploying religious structures and artifacts for secular purposes, and thereby denuding them of reverence, was itself a strategy of sterilization and desacralization that must be situated on a continuum with iconoclasm. It redeemed them from idolatrous abuse and reversed the

\footnotetext{
${ }^{25}$ See, for instance, Peacock, English Church Furniture, 48, 49, 53, 77, 83, 95, 105, 129, 130, 137, 159, 165, 170.

${ }^{26}$ John Calvin, A Very Profitable Treatise ... Declarynge what Great Profit might Come to al Christendome, if there were a Regester Made of all Sainctes Bodies and other Reliques (London, 1561). See also Thomas Becon, The Monstrous Marchandise of the Romishe Byshops, in The Worckes of Thomas Becon (London, 1564), pt. 3.

${ }^{27}$ John Foxe, Actes and Monuments (London, 1570), 1483.

${ }^{28}$ "Homilie against perill of Idolatrie," 15, 60.

${ }^{29}$ On adiaphora, see John S. Coolidge, The Pauline Renaissance in England: Puritanism and the Bible (Oxford: Clarendon, 1970), esp. chap. 2; Ethan Shagan, "The Battle for Indifference in the English Reformation," in Moderate Voices in the European Reformation, ed. Luc Racaut and Alec Ryrie (Aldershot: Ashgate, 2005), 122-144; and Bynum, "Are Things 'Indifferent'?," esp. 111 .

${ }^{30}$ See Barrow, Briefe Discoverie, 132; and Smyth, Parallels, censures, observations, 121-122, who repudiated the precedent that heathen temples had been converted into the houses of God.
} 
process by which they had been rendered holy in the first place. It was the opposite of "sanctification," which Thomas Wilson defined in his well-known Christian dictionarie as "the separation of things . . . from common or prophane use." ${ }^{\prime 31}$ And it entailed spatial relocation as well as physical adaptation: the translation of the sacred into non-ecclesiastical and secular contexts in which they were no longer so vulnerable to veneration. ${ }^{32}$ Their migration into domestic, industrial, and other domains also involved placing them in the hands of ordinary laypeople. It struck a blow at the notion that the clergy were a special caste of intermediaries between God and human beings who alone had the right to touch holy things.

At the heart of the twin processes of iconoclasm and conversion was an attempt to reform memory. The former has aptly been described as "a sacrament of forgetfulness," but the phrase might equally be applied to recycling. ${ }^{33}$ In both cases, Protestants were torn between impulses that drew them in the direction of complete obliteration and others that favored the retention of some remnants of the vanquished past. Ecclesiastical edicts issued from the Henrician period onward called for the removal of "monuments of superstition" and "idolatry" so that "no memory remained" of them. ${ }^{34}$ Fearing that the visible traces of destroyed images might perpetuate error and that empty voids could become a focus for false worship themselves, some bishops gave strikingly precise instructions. John Parkhurst's injunctions and interrogatories for Norwich in 1561 required that the niches and tabernacles in which statues had once stood should be filled up "so as if there had been none there" and that holy water stoups should be "clean taken away." 35 Similarly, Edwin Sandys's articles for York Province in 1578 called for the demolition of altars "even unto the foundation": the space where they had stood was to be paved and the walls to which they were adjacent were to be "made uniform with the rest, so as no breach or

\footnotetext{
${ }^{31}$ Thomas Wilson, A Christian Dictionarie Opening the Signification of the Chiefe Words Dispersed Generally through Holy Scriptures of the Old and New Testament (London, 1612), 422; and Thomas Blount, Glossographia, or, a Dictionary Interpreting all such Hard Words of Whatsoever Language now used in our Refined English Tongue (London, 1661), sig. Mm3v. See also Henry Bullinger, Fiftie Godlie and Learned Sermons divided into Five Decades, trans. H. I. (London, 1577), 979; and Peter Martyr Vermigli, Common Places (London, 1583), 163.

${ }^{32}$ Ronald Hutton has traced a similar process in relation to seasonal rituals: "The English Reformation and the Evidence of Folklore," Past and Present 148 (August 1995): 89-116.

${ }^{33}$ Eamon Duffy, The Stripping of the Altars: Traditional Religion in England c.1400-c.1580 (New Haven, Conn.: Yale University Press, 1992), 480.

${ }^{34}$ Edward Cardwell, ed., Documentary Annals of the Reformed Church of England (Oxford: University Press, 1844), 1:6-7, 17, 212, 221.

${ }^{35}$ Walter Frere and William Kennedy, eds., Visitation Articles and Injunctions of the Period of the Reformation, Alcuin Club Collections 14-16 (London: Longmans, Green, 1910), 3:100, see also $3: 323,335$.
} 
rupture appear. ${ }^{\not 36}$ Others apparently felt that the sight of broken idols would be an effective prophylactic against backsliding, a constant reminder of the overthrow of corruption and of the victory of the Gospel. In order to forget, it was necessary to remember. Remodeled objects operated in the same way as mutilated fragments, as trophies and tokens of the defeat of antichrist and the devil. They were tangible symbols of how Christianity had, quite literally, been re-formed in the mid-sixteenth century. ${ }^{37}$ It is telling that officials were insistent that redundant liturgical furnishings should be "broken," "defaced," and "cut in pieces" before being put to alternative uses. ${ }^{38}$

Regardless of whether they were destroyed or altered, the transformation of such objects represented an assault upon what Eamon Duffy calls a "complex indoor landscape of memory." ${ }^{\prime 39}$ Bearing witness to the intense devotional and emotional commitment of the late medieval laity, ecclesiastical plate, ornaments, and vestments not only served vital ritual purposes, they also functioned as memorials to the people who had donated them and as invitations to pray for their souls. Sometimes inscribed with invocations in Latin or English, they were a stimulus to a form of remembering that had soteriological efficacy. Some such objects survived the Reformation, including a Eucharistic vessel owned by the parish church of West Drayton in Middlesex marked with the words Orate pro a[n]i[m]abus Johis Propyll et Johanne uxor'ei (pray for the souls of John Propyll and Johanne his wife) written on its foot. ${ }^{40}$ But in many other cases, the only trace that remains is a written one: a silver parcel gilt chalice marked with "Pray ye for the sowles of Walter Hynde and Alis his Wif," for instance, was included in a 1474 inventory of the church goods of Saint Edmund's Church, Salisbury. ${ }^{41}$ Explicitly linking items given as gifts or funded by bequests with their donors, such lists functioned as a kind of bede-roll themselves. One prepared for the church of Long Melford on the eve of the Reformation in 1529 includes a cope of crimson velvet presented by William Deek and his wife, Margery; an antiphoner donated by Sir Thomas Turret; and three altar cloths provided by the widow Joan Foot, as well as various items funded by local guilds. ${ }^{42}$ Even where such objects bore no marks of provenance, their mere

\footnotetext{
${ }^{36}$ W. P. M. Kennedy, ed., Elizabethan Episcopal Administration, 3 vols., Alcuin Club Collections 25-27 (London: A. R. Mowbray, 1924): 2:98, see also 3:227.

${ }^{37}$ See Margaret Aston, "Public Worship and Iconoclasm," in Archaeology of the Reformation, ed. Gaimster and Gilchrist, 16-17.

${ }^{38}$ These phrases are ubiquitous in the Lincolnshire returns: Peacock, English Church Furniture.

${ }^{39}$ Duffy, "End of it all," 110.

${ }^{40}$ Cox and Harvey, English Church Furniture, 38.

${ }^{41}$ J. E. Nightingale, The Church Plate of the County of Wiltshire (Salisbury: Bennet Bros., 1891), 13.

${ }^{42}$ David Dymond and Clive Paine, eds., The Spoil of Melford Church: The Reformation in a Suffolk Parish (Ipswich: Salient, 1992), 10-23, esp. 15, 19.
} 
presence was a mnemonic to dead relatives, neighbors, and friends. The confiscation, destruction, and modification of such objects under Henry VIII, Edward VI, and Elizabeth I silenced the patterns of intercessory prayer that Protestantism rejected as unscriptural innovations. As Duffy comments, the bureaucratic catalogues that document this process have an "amnesiac" quality. Editing out the memory of the past benefactors of the parish, they sought to "transform the named deposit of meritorious giving into so much saleable lumber," into disinterested commodities bereft of the cargo of affective remembrance. ${ }^{43}$ Ironically, however, in so doing they also kept a record of them for posterity.

\section{Converting Church Furniture}

It is now time to examine the precise ways in which the sacred was recycled in greater detail. The first category of items consists of liturgical books. Large numbers of such texts were cut up and reused by bookbinders, who purchased them as a source of scrap paper, parchment, and vellum. Others served commercial and culinary purposes: the churchwardens of the Lincolnshire parish of Horblinge reported in 1566 that they had recently sold a job lot of mass books, portasses, manuals, legends, and grails to a certain John Craife, who, they declared, had "defaced the same in teringe and breaking of theim to put spice in." 44 However, many missals, primers, ordinals, and processionals managed to weather the storm of the Reformation by being selectively sanitized. They often bear evidence of compliance with the Henrician proclamation of 1538 that ordered the name of Thomas Becket to be systematically struck out of such texts and with the wider drive to obliterate the memory of the papacy's usurped jurisdiction over English religious affairs and to prune the ecclesiastical calendar of the feast days of dubious saints. ${ }^{45}$ The wording of Edward VI's proclamation of 1549 ordering liturgical books to be "so deface[d] and demolish[ed], that they never hereafter may serve either to any such use as they were first provided for, or be at any time a let to that godly and uniform order" set forth in the Book of Common Prayer is telling: it leaves a loophole within which such texts, suitably modified, might still find a legitimate place in reformed worship, at least in the short term. ${ }^{46}$ One compelling example is a

\footnotetext{
${ }^{43}$ Duffy, "End of it all," 114. See also Duffy, Stripping of the Altars, 494-495.

${ }^{44}$ Peacock, English Church Furniture, 107.

${ }^{45}$ See Martha W. Driver, The Image in Print: Book Illustration in Late Medieval England and its Sources (London: British Library, 2004), chap. 6; Aude de Mézerac Zanetti, "Liturgical Changes to the Cult of Saints under Henry VIII," in Saints and Sanctity, ed. Peter Clarke and Tony Claydon, Studies in Church History (Woodbridge: Boydell and Brewer, 2007), 126-143.

${ }^{46}$ Hughes and Larkin, Tudor Royal Proclamations, 1:485-486.
} 
mid-fifteenth century Sarum processional in Salisbury Cathedral Library, from which pages have been removed, indulgences systematically scratched out, ritual formulae crossed through, and an inventory of relics heavily blotted with ink, but into which has also been inserted new material, including the text of the Oath of Supremacy. ${ }^{47}$

Copies of Jacobus de Voragine's famous thirteenth-century collection of saints' lives, the Golden Legend, and images of pity showing Christ crucified surrounded by the instruments of the passion were similarly altered and annotated in ways that enabled these books and broadsides to be used in a post-Reformation world. ${ }^{48}$ Some such changes focused on removing objectionable features; others sought to neutralize the dangers posed by "popish" books by adding comments that urged readers to beware of the dangers they contained. Rendering these bibliographical objects safe for Protestant use, such strategies may be seen as a kind of fireproofing. They transformed them into mirrors in which to see the evils of impiety and idolatry. ${ }^{49}$ Indicative of the complicated relationships between medieval Catholicism and its Protestant successor, as Martha Driver comments, such examples remind us that "the reformed religion was not made new out of whole cloth." ${ }^{50}$

This observation rings no less true in the case of the vast array of vestments that parish churches had accumulated during the Middle Ages. The elaborate copes, tunicles, and albs in which priests and their acolytes had once celebrated mass were too closely connected with the theology of the real presence to survive the Reformation as suitable garb for Protestant ministers. Some were taken away, sold off, or melted down because of precious metallic threads with which they were embroidered. But in other cases, the fabric was reworked to form coverings for the new communion table. The parish of Dartford in Kent declared in 1552 that they had reused a red silk canopy and tunicle for this purpose. ${ }^{51}$ Two copes were cut up in a similar

\footnotetext{
${ }^{47}$ MS 148, Salisbury Cathedral Library, Salisbury. This has been reproduced in facsimile: Alastair Lack, ed., Processions and Other Late Mediaeval Ceremonies of Salisbury Cathedral (Salisbury, 2015).

${ }^{48}$ See Morgan Ring, "The Golden Legend and the English Reformation, c 1483-1625," (PhD diss., University of Cambridge, 2016), chap. 5; and Ring's forthcoming article, "Annotating the Golden Legend in Early Modern England." On indulgenced images, see Driver, Image in Print, 206-208.

${ }^{49}$ See also Alison Shell, "Catholic Texts and Anti-Catholic Prejudice in the 17th-century Book Trade," in Censorship and the Control of Print in England and France 1600-1910, ed. Robin Myers and Michael Harris (Winchester: St Paul's Bibliographies, 1992), 33-57.

${ }^{50}$ Driver, Image in Print, 204.

51"Inventories of Parish Church Goods in Kent, A.D. 1552," ed. M. E. C. Walcott, R. P. Coates, and W. A. Scott Robertson, Archaeologia Cantiana 8 (1872): 141.
} 
fashion at Burnham in Buckinghamshire. ${ }^{52}$ At Haconby in Lincolnshire, vestments were turned into a cloth to hang in front of the pulpit, and in Stallingbrook they were transformed into "comlie clothes" for the same items of church furniture. In Braceby, an alb was repurposed to adorn the font, while at Denton and Tallington others were made into a surplice. ${ }^{53}$ The survival of the latter was, of course, a source of deep concern to puritans, who regarded this "rag of Rome" as an insupportable relic of the popish past and refused to wear it in defiance of official edicts. During the Vestiarian Controversy in the $1560 \mathrm{~s}$, many preferred to be suspended rather than to dress in garments that might mislead the "weaker brethren." 54 This was a running sore for many years to come, but in the 1640 s, some finally had the opportunity to take their revenge: Parliamentary soldiers who plundered the church of Hillingdon in 1642 requisitioned and ripped up the surplice to make themselves handkerchiefs, and one of the company wore it to the next stop on their iconoclastic tour, Uxbridge. ${ }^{55}$

Much of the redundant textile "trumpery" left over from medieval Catholicism was likewise recycled in the first phase of England's long Reformation. Vestments and veils were turned into doublets and other types of apparel, hangings, tablecloths, and cushions. In Exeter, for instance, the best cope of Saint Peter's parish, made of "cloth of tissue," was cut up to make the "sparwer," or canopy for a bed. ${ }^{56}$ What happened to the painted cloths that had previously hung before the high altar during Lent at All Hallows London Wall which were sold to Peter Smythe, or to the coat worn by the statue of Our Lady in a church on Bread Street and purchased by William Gibson before 1552, is not recorded. ${ }^{57}$ Some of the work involved in putting such "naperie" to "prophane use" was carried out by professional tailors, but much no doubt was done by women in the home. In Braunston, Lincolnshire, Robert Bellamee purchased two corporals in 1566, "whereof his wife made of one a stomacher for her wench and of thother being ript she will make a purse." A smaller cloth had been sold to John Storr, whose spouse "occupieth yt in wiping her eies." ${ }^{58}$ In Welby, the rood cloth and

\footnotetext{
${ }^{52}$ F. C. Eeles and J. E. Brown, ed., The Edwardian Inventories for Buckinghamshire, Alcuin Club Collections 9 (London: Longmans, Green, 1908), 50. This same occurred at Alford in Lincolnshire: Peacock, English Church Furniture, 29.

${ }_{53}^{53}$ Peacock, English Church Furniture, 94, 144, 54, respectively.

${ }^{54}$ See Patrick Collinson, The Elizabethan Puritan Movement (London: Jonathan Cape, 1967), chaps. 2, 4 .

${ }^{55}$ William Douglas Hamilton, ed., Calendar of State Papers Domestic of the Reign of Charles I (London: Her Majesty's Stationery Office, 1887), 372.

${ }^{56}$ Beatrix F. Cresswell, ed., The Edwardian Inventories for the City and County of Exeter, Alcuin Club Collections 20 (London: A. R. Mowbray \& Co., 1916), 78.

${ }^{57}$ H. B. Walters, ed., London Churches at the Reformation with an Account of their Contents (London: Society for the Promotion of Christian Knowledge, 1939), 117, 91, respectively.

${ }^{58}$ Peacock, English Church Furniture, 56-57.
} 
"such like linen bagidg" were transformed by housewives into sheets and smocks for their children. ${ }^{59}$ The Reformation is a neglected chapter in the history of secondhand clothing and of the culture of mending. ${ }^{60}$

In several interesting instances, vestments became costumes for theatrical performances: at Horbling in Lincolnshire, a cope was given to a scholar who made it into "a player's cote." ${ }^{\prime \prime 1}$ This must have seemed a fitting fate for such "pelfry" to hot Protestants for whom the mass was a "mummery." Many more, however, were given to fellow villagers who found themselves in dire financial need. ${ }^{62}$ As Ethan Shagan has commented, "we should not underestimate the spiritual significance of seeing the local poor sleeping in the streets under albs and altar cloths." ${ }^{\circ 3}$ This was a type of recycling that was consistent with Protestant values: insistent that the sick and indigent were the true images of Christ, the reformers constantly called for the wealth lavished on decorating churches to be diverted to social welfare. ${ }^{64}$

In the 1630s, the Laudian campaign to restore the beauty of holiness pushed back against Calvinist austerity and may have created new opportunities for the reuse of medieval ecclesiastical embroideries that had gone underground or found asylum in private homes. Some splendid copes and vestments had already been cut up to form coverings for tables and cloths for pulpits: the remarkable embroidered frontals preserved at Steeple Aston in Oxfordshire were composed from a fourteenth-century cope and include scenes from the life of Christ, the Virgin Mary, and twenty saints. It is possible that this was done at the time of the break with Rome, but it may also have occurred much later. ${ }^{65}$ The systematic restoration of altars in the seventeenth century probably provided an incentive to rework surviving vestments to adorn the stone structures reerected and railed off in chancels. Once the apparatus of priests who performed the miracle of transubstantiation, now they lent renewed weight to the idea that what happened during the Eucharist

\footnotetext{
${ }^{59} \mathrm{Ibid} ., 159$, and see also 71.

${ }^{60}$ On these themes, see Margaret Spufford, The Great Reclothing of Rural England: Petty Chapmen and their Wares in the Seventeenth Century (London: Hambledon, 1984); and Abigail Shinn, "Cultures of Mending," in The Ashgate Research Companion to Early Modern Popular Culture, ed. Shinn, Matthew Dimmock, and Andrew Hadfield (Farnham: Ashgate, 2014), 235-252.

${ }^{61}$ Peacock, English Church Furniture, 107-108.

${ }^{62}$ For examples, see ibid., 30, 119; and Eeles and Brown, Edwardian Inventories for Buckinghamshire, 82-83.

${ }^{63}$ Shagan, Popular Politics, 298.

${ }^{64}$ As articulated in the "Homilie against perill of idolatrie," 74. See also Lee Palmer Wandel, Always Among Us: Images of the Poor in Zwingli's Zurich (Cambridge: Cambridge University Press, 1990).

${ }^{65}$ Claire Browne, Glyn Davies, and M. A. Michael, eds., English Medieval Embroidery: Opus Anglicanum (New Haven, Conn.: Yale University Press, 2016), 190-195.
} 
involved some kind of real presence.$^{66}$ It is equally difficult to date the cushion or kneeler reworked from a late fourteenth-century orphrey band, now preserved in the Victoria and Albert Museum, but once owned by the church of Saint Leonard, Catworth, Huntingdon. It too is an ancient Catholic object that has survived because it successfully negotiated the transition to Protestant worship (fig. 1). ${ }^{67}$

The religious upheavals associated with the long Reformation also released large quantities of stone, timber, and lead for reuse. The plundering of the abbeys and priories for building material has been thoroughly explored by archaeologists, especially in connection with the construction of grand country houses for the gentry and nobility. Former monastic houses refurbished as residences sometimes incorporated earlier features: the conversion of the Charterhouse in Coventry for its owner Henry Over involved turning a sandstone altar table decorated with the Five Wounds of Christ into a mantelpiece. ${ }^{68}$ In towns and cities, the dismantling of chantry chapels supplied the necessary stone for civic amenities: in Lincoln, the chantry of a former mayor Ranulph Kyme was converted into an elaborate conduit head that was arguably designed to preserve the memory of this worthy after the death of purgatory. ${ }^{69}$

The process of purging parish churches of "popish superstition" and befitting them for the reformed liturgy flooded the market with other reusable goods. In Newcastle, bells and lead expropriated by the state in 1552 were converted into guns, bullets, and shot and used to fortify towers in the context of the brief war with Scotland. ${ }^{70}$ The Lincolnshire inventories of 1566 show that other obsolete pieces of church furniture had varied afterlives. Altar stones were laid as pavements, turned into steps, and broken up to repair highways and bridges. As Margaret Aston remarks, "the continuous trampling of passing feet" was itself an ongoing ritual of humiliation. ${ }^{71}$ One taken out of the church of

\footnotetext{
${ }^{66}$ On the Laudian programme, see Kenneth Fincham and Nicholas Tyacke, Altars Restored: The Changing Face of English Religious Worship, 1547-c.1700 (Oxford: Oxford University Press, 2007), chaps. 5-6. For a list of medieval embroidered items surviving in English churches in the early twentieth century, see Cox and Harvey, English Church Furniture, 345-350.

${ }^{67}$ See "Orphrey (cushion)," no. 837-1902, Victoria and Albert Museum, accessed 12 March 2017, http://collections.vam.ac.uk/item/O129343/orphrey-cushion-unknown/.

${ }^{68}$ Iain Soden, "The Conversion of Former Monastic Buildings to Secular Use: The Case of Coventry," in Archaelogy of the Reformation, ed. Gaimster and Gilchrist, 285.

${ }^{69}$ See David Stocker with Paul Everson, "Rubbish Recycled: A Study of the Re-Use of Stone in Lincolnshire," in Stone: Quarrying and Building in England AD 43-1525, ed. David Parsons (Chichester: Phillimore, 1990), 97. On the Kyme chantry, see David Stocker, "Archaeology and the Reformation: A Case Study of the Redistribution of Building Materials in Lincoln, 1520 1560," Lincolnshire History and Archaeology 25 (1990): 18-32.

${ }^{70}$ William Page, ed. The Inventories of Church Goods for the Counties of York, Durham, and Northumberland, Surtees Society 97 (Durham, 1897), xvii.

${ }^{71}$ Peacock, English Church Furniture, 39, 41, 48, 55, 65, 74, 84, 93, 107, 150; and Aston, Broken Idols, 178.
} 


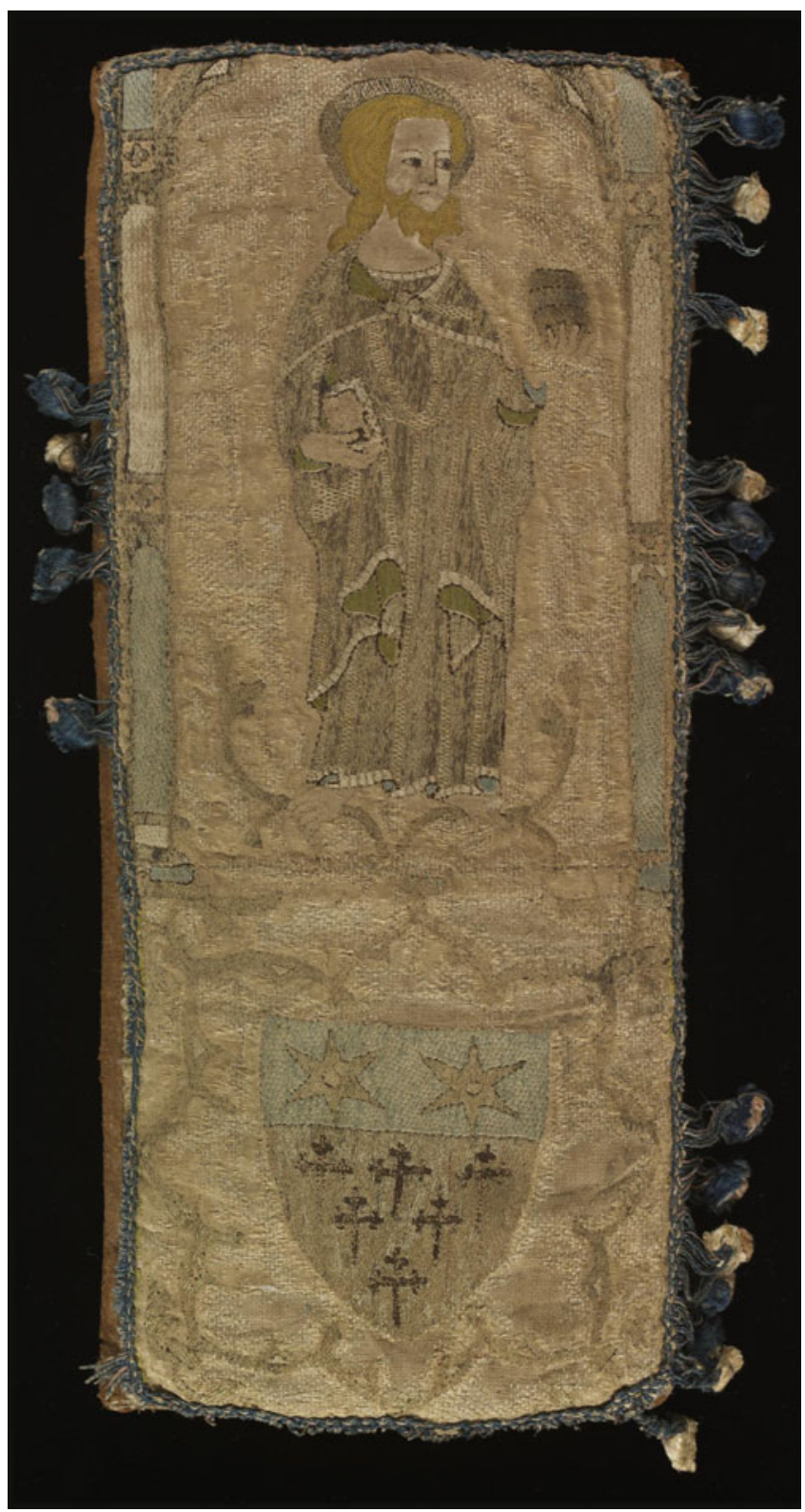

Fig. 1. Fourteenth-century orphrey band made into a cushion, once owned by Saint Leonard's church, Catworth, Huntingdon: No. 837-1902, Victoria and Albert Museum, http://collections. vam.ac.uk/item/O129343/orphrey-cushion-unknown/. 
Boothby Pagnell by Francis Pennell in 1563 was made into a fire hearth in the great hall of his house. ${ }^{72}$ Holy water stoups were similarly turned into mortars, milk vessels, cisterns, sinks, and troughs for swine, ${ }^{73}$ and in Gonerby a container created for holy bread became a basket for carrying fish. ${ }^{74}$ The wood from dismantled rood lofts was repurposed in farmyards as pens for cattle and sheep, as well as used to make desks, windows, and weavers' looms, build steeples, and fix churchyard seats and fen gates. ${ }^{75}$ This was an ongoing process that extended over a number of decades, especially in what Protestants regarded as the "dark corners of the land." In his injunctions for the Welsh diocese of Saint David's in 1583, Bishop Middleton explicitly ordered that the rubble and timber left behind after the demolition of altars and rood lofts should be turned to "some good uses." "76 To convert objects rightly reduced to rubbish by godly zeal into utilitarian items was not just acceptable; it was the kind of thrift and good stewardship of scarce resources upon which Protestantism prided itself. ${ }^{77}$

As in the case of books and vestments, some of these structures were put to alternative ecclesiastical purposes. Especially in Norfolk and Devon, many roodscreens escaped complete demolition, and were truncated at the waist, the panels depicting the saints beneath cursorily scratched through or whitewashed and then overpainted with blackletter verses from scripture. At Binham, the figures of the Man of Sorrows, Saint Michael, and Saint Catherine now shine through texts from Cranmer's 1539 Bible. $^{78}$ Even more compelling is the rare late medieval panel painting dating from circa 1460 depicting the betrayal of Christ and the kiss of Judas from the church of Saint Mary, Grafton Regis, Northamptonshire, recently purchased by the Fitzwilliam Museum in Cambridge. Analysis using infrared light suggests that this offending image was reversed and turned into a table of the Ten Commandments, another innovation commanded by the crown (fig. 2) ${ }^{79}$ Other images on wood, such as the picture of two Franciscan friars at All

\footnotetext{
${ }^{72}$ Ibid., 54.

${ }^{73}$ Ibid., 20, 41, 65, 94, 111.

${ }^{74}$ Ibid., 86.

${ }^{75}$ Ibid., 54, 70, 73, 77, 107, 132, 146.

${ }^{76}$ Kennedy, Elizabethan Episcopal Administration, 3:150. See also the visitation articles for the prebend of Wistow, Yorkshire, in J. S. Purvis, Tudor Parish Documents of the Diocese of York (Cambridge: Cambridge University Press, 1948), 48.

${ }^{77}$ See Joshua J. Yates and James Davison Hunter, Thrift and Thriving in America: Capitalism and Moral Order from the Puritans to the Present (Oxford: Oxford University Press, 2011).

${ }^{78}$ Aston, Broken Idols, 920-921; and Lucy J. Wrapson, "East Anglian Medieval Church Screens: A Brief Guide to their Physical History," Hamilton Kerr Institute Bulletin, no. 4 (2013), 33-47.

79،"The Kiss of Judas," PD.2-2012, The Fitzwilliam Museum, Cambridge, accessed 1 November 2017, http://data.fitzmuseum.cam.ac.uk/id/object/186329.
} 


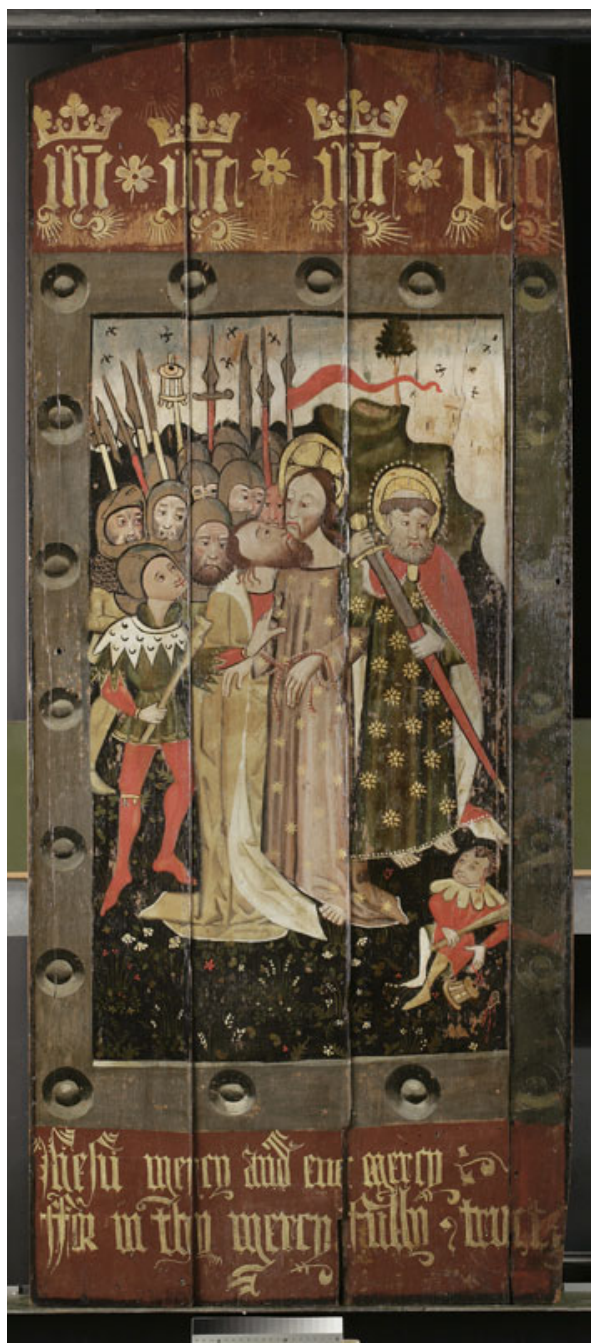

Fig. 2. Panel painting depicting the betrayal of Christ and the kiss of Judas, ca. 1460, from the church of Saint Mary, Grafton Regis, Northamptonshire. The reverse appears to have been recycled as a table of Ten Commandments: [British School, Coventry?], The Kiss of Judas, PD.2-2012, Fitzwilliam Museum, Cambridge, http://data.fitzmuseum.cam.ac.uk/id/object/186329.

Hallows Bread Street in London, were "spoyled cut and defaced" before being auctioned off. The sum secured for this item in 1552 was one shilling and four pence. ${ }^{80}$

\footnotetext{
${ }^{80}$ Walters, London Churches, 86.
} 
Holy water stoups were occasionally transformed into fonts, as at Moresby in Cumberland, though it remains difficult to date such conversions. ${ }^{81}$ Fonts themselves became victims of puritan rage in the mid-seventeenth century and the Directory for Public Worship ordered their replacement by mere basins attached to the pulpit. ${ }^{82}$ Some of those found concealed under the floor of churches may reflect attempts to preserve them from the Roundheads; others were plastered over to obliterate their superstitious carvings. ${ }^{83}$ Altar stones too were reused inside as well as outside church buildings, a practice that had a parallel in Zurich, where Zwingli deployed them to build a new chancel screen in the Grossmünster, which bore the pulpit from which he preached. $^{84}$ Such modifications reinforce the observation that the reformers did not begin with a clean slate; they assimilated the physical landscape of the Catholic past to create a mosaic of old and new materials capable of provoking competing memories and mixed emotions.

Similar patterns of reconfiguration appear when we turn to church plate. As noted above, under Edward VI, much sacred silver and gilt was reduced back to its raw state to fill the crown's hungry coffers. The chalices and patens that parishes were permitted to keep were not always cleansed of their traditional Catholic iconography: at Sturminster Marshall in Dorset, the bowl still showed the crucifixion under an ogee arch, the monogram INRI, and the attendant figures of John the Evangelist and the Blessed Virgin Mary long after the Reformation. ${ }^{85}$ Others were reshaped to make them suitable for administering the Protestant Eucharist. In the Elizabethan period, the shallow vessels typical of the Middle Ages were gradually replaced by the larger bell-shaped cups necessary to dispense communion in both kinds to the laity. Some of these seem to have been made from preexisting plate and among the examples preserved in the Victoria and Albert Museum are cups made

\footnotetext{
${ }^{81}$ Cox and Harvey, English Church Furniture, 238.

${ }^{82}$ See Spraggon, Puritan Iconoclasm, 79-80. Cox and Harvey, English Church Furniture, chap. 6, p. 182 cites a font at Newark in Nottinghamshire, which has an accompanying brass plate inscribed "This Font was demolished by the Rebels, May 9, 1646, and rebuilt by the charity of Nicholas Ridley in 1660."

${ }^{83} \mathrm{Cf}$. the medieval examples of reverent font burial discussed in David Stocker, "Fons et Origo: The Symbolic Death, Burial and Resurrection of English Font Stones," Church Archaeology 1 (1997): 17-25. For buried fonts at Grappenhall and Alderley Cheshire, see Cox and Harvey, English Church Furniture, 188. See also Aston, Broken Idols, 595-604; and Trevor Johnson, "Brass, Glass and Crosses: Identifying Iconoclasm outside the Journal," in Journal of William Dowsing, ed. Cooper, 89-106, 96-97.

${ }^{84}$ Cited in Heal, "Visual and Material Culture," 607.

${ }^{85}$ J. E. Nightingale, The Church Plate of the County of Dorset (Salisbury: Bennet Bros., 1889), $128-130$.
} 


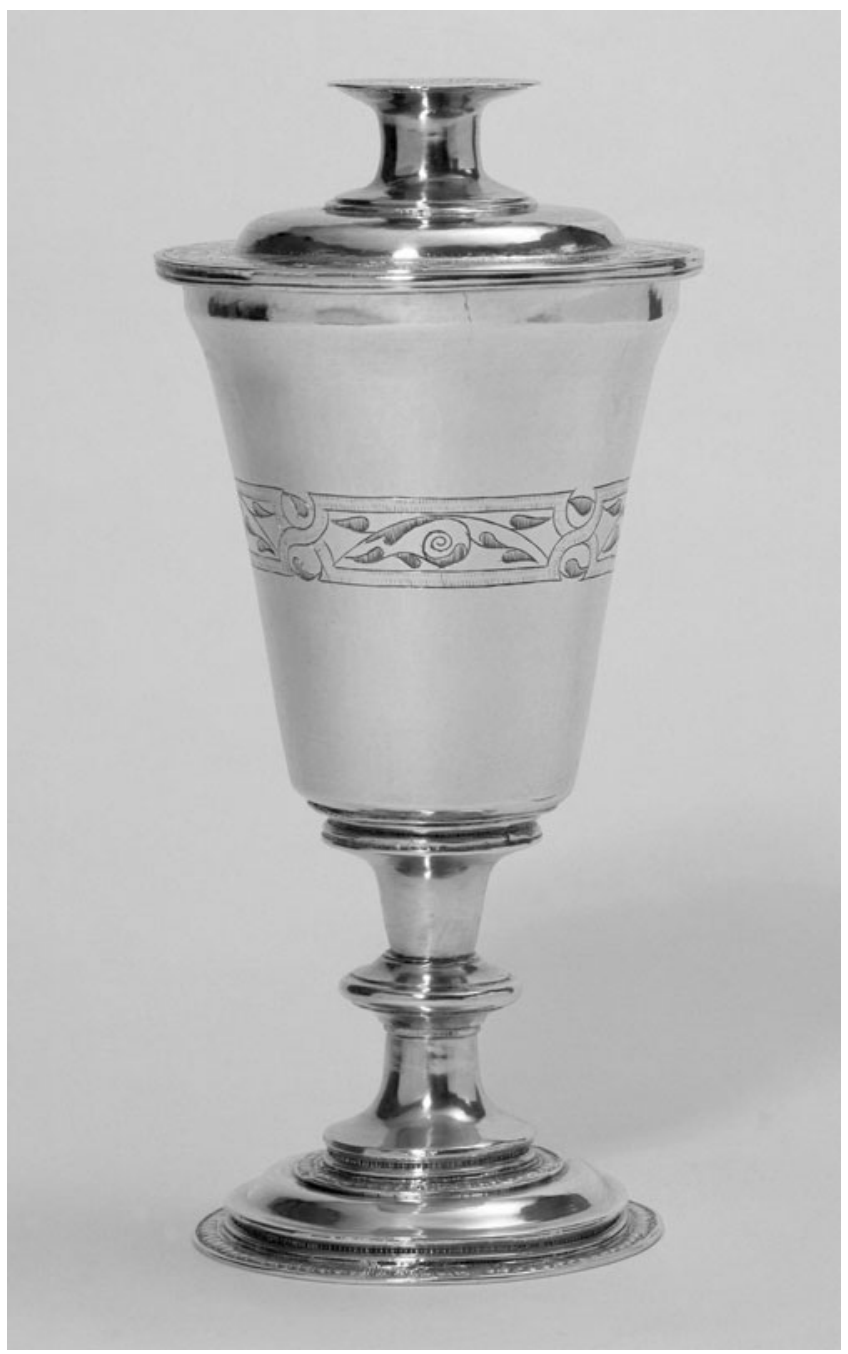

Fig. 3. Communion cup and paten cover, made ca. 1571-1574 from an earlier chalice, by John Jones, Exeter: No. 4636-1858, Victoria and Albert Museum, http://collections.vam.ac.uk/item/ O10949/communion-cup-and-jones-john/.

circa 1566-1567 for Saint Mary the Virgin, Chessington, Surrey, and circa 1571-1574 for a church in Exeter (fig. 3). ${ }^{86}$ The cover of the chalice at Little Birch in Herefordshire bearing the date 1576 was probably made out

86“"Communion Cup," no. Loan:Chessington.1, Victoria and Albert Museum, accessed 12 March 2017, http://collections.vam.ac.uk/item/O117605/communion-cup-unknown/; “Communion Cup 
of the ancient paten. ${ }^{87}$ On another from Thornage in Norfolk was inscribed "The fashen altred by I. Stalom d.a $\mathrm{a}^{\mathrm{o}}$ 1563." Also bearing the legend "This is ye gyfte of John Bates and Margret hys wyfe, 1456," this was an item that preserved the memory of its medieval donors in an approved Protestant manner. ${ }^{88}$ In other instances, including a pyx bequeathed to the parish of Saint Martin, Ludgate in 1533, which was converted to a communion cup around 1559-1560, prohibited formulae remained: the foot of the chalice bears the words "praye for the salles of stewyn pekoc \& marget hys wyffe Wyche gave thys in the wusseppe of the sacrement." 89 Communion plate thus continued to function as a carrier of biographical memory long after the Reformation. This was a trend, moreover, that Protestantism encouraged rather than brought to an end. Devout people who bestowed gifts on their parishes continued to pay for their names to be inscribed on them. The theological rationale for donation changed, but patterns of giving and commemoration continued. ${ }^{90}$

Like the other classes of object already discussed, medieval liturgical silverware was also sold off to craftsmen. In Edwardian London, members of the goldsmiths' company such as Anthony Rowell, John Cooke, and John Daniell eagerly snapped up crosses, monstrances, censers, and paxes that were no longer necessary for worship. ${ }^{91}$ Elsewhere, such items were purchased by scrap metal merchants: a chrismatory from Aswardby in Lincolnshire, for instance, was sold to a tinker, though "yt was first broken in peces," as was a cross sold by the churchwardens at Laughton around $1546 .{ }^{92}$ Some such metal was recycled for other purposes, including the creation of salt cellars that combined aesthetic attractiveness with functionality. The Stonyhurst Salt in the British Museum, which was made around 1577, incorporates parts salvaged from melted-down church plate, including gemstones and pieces of rock crystal that date from between the thirteenth and fifteenth centuries (fig. 4). Salt had a sacred symbolism and resonance that ensured that this remodeled object retained its spiritual significance after

and Paten Cover," no. 4636-1858, Victoria and Albert Museum, accessed 12 March 2017, http:// collections.vam.ac.uk/item/O10949/communion-cup-and-jones-john/.

${ }^{87} \mathrm{Cox}$ and Harvey, English Church Furniture, 38.

${ }^{88}$ Ibid., 37.

${ }^{89}$ Walters, London Churches, 27.

${ }^{90}$ Many examples are cited in Nightingale, Church Plate of the County of Wiltshire and Church Plate of the County of Dorset. For the meanings and functions of Protestant church plate, see Mark Peterson, "Puritanism and Refinement in Early New England: Reflections on Communion Silver," William and Mary Quarterly, 3rd ser., 58, no. 2 (April 2001): 307-346.

${ }^{91}$ See Walters, London Churches, 59, 60, 96, 123, 127, 137, 349, 457, among many references to items acquired by goldsmiths.

${ }^{92}$ Peacock, English Church Furniture, 33, 112. 


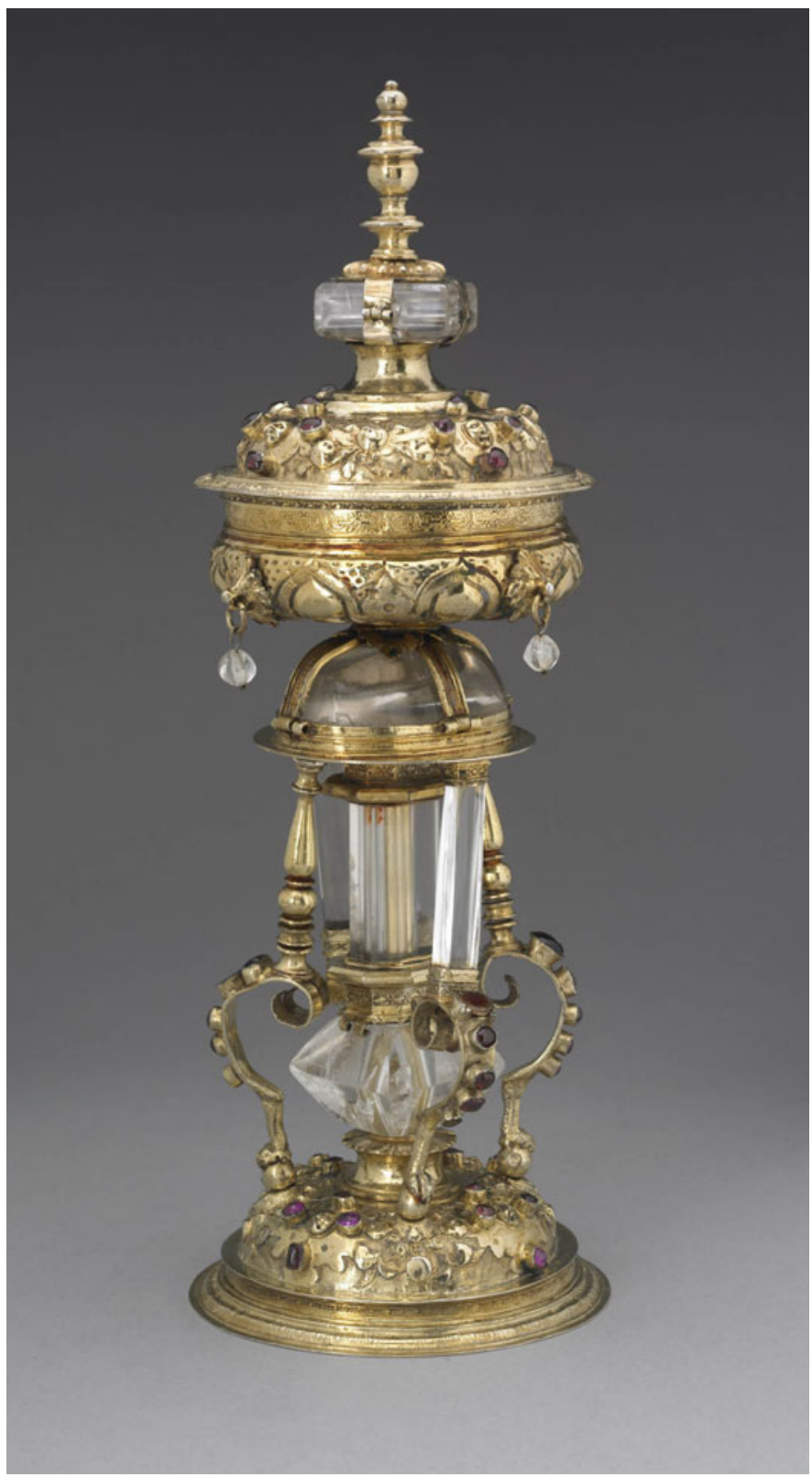

Fig. 4. [John Robinson?], "Stonyhurst Salt," ca. 1577, 1958,1004.1, British Museum, London, http://www.britishmuseum.org/research/collection_online/collection_object_details.aspx?objectId= 70900\&partId=1. 
the Reformation. ${ }^{93}$ In turn, reliquaries were likewise reinvented as tableware. An example in the Victoria and Albert Museum associated with the Poor Clares seems to have subsequently been restored to religious use. ${ }^{94}$ Completing the circle, secular drinking vessels, such as tankards, were sometimes transferred from domestic settings to the parish church to serve as flagons for communion wine: examples dating from 1572 and 1589 were documented at Fugglestone and Teffont Evias in Wiltshire in the nineteenth century. ${ }^{95}$

Intriguingly, other Catholic "trinkets" of this kind were turned into toys. In Broughton in Lincolnshire, two pyxes were first defaced and then given away to a child "to plaie with all." "96 Described by the Marian priest Roger Edgeworth in a sermon delivered during Mary's reign, this was a novel strategy of desacralization deployed on the European continent too. ${ }^{97}$ In Cologne in 1536, a man pulled the arms off a crucifix and handed it to his children. Fingering such puppets and "mawmets" in a spirit of laughter and fun was a powerful mechanism for imbuing the next generation with contempt for the pope and his minions. It translated the commonplaces of Protestant polemic into practical action. ${ }^{98}$

\section{Motives, Meaning, And Memory}

The difficulty of discerning the intentions that lay behind these object transformations is often acute. As the authorities themselves recognized, the

\footnotetext{
93“The Stonyhurst Salt, c. 1577," 1958,1004.1, British Museum, London. For a stimulating discussion of this object and the wider phenomenon, see Victoria Yeoman, "Reformation as Continuity: Objects of Dining and Devotion in Early Modern England," (forthcoming). I am grateful to Dr. Yeoman for permitting me to read and cite this in advance of publication.

${ }^{94}$ LOAN:MET ANON.11-2007, Victoria and Albert Museum, London, http://collections.vam.ac. uk/item/O142161/reliquary-partridge-affabel/. I am grateful to Tessa Murdoch for sharing her expertise regarding this item. On the transformation of reliquaries into works of art, see Alexander Nagel, "The Afterlife of the Reliquary," in Treasures of Heaven: Saints, Relics, and Devotion in Medieval Europe, ed. Martina Bagnoli, Holger A. Klein, C. Griffith Mann, and James Robinson (London: British Museum Press, 2010), 211-222.

${ }^{95}$ Nightingale, Church Plate of the County of Wiltshire, 25, 53. It is not clear when these secular vessels became communion ware.

${ }^{96}$ See Peacock, English Church Furniture, 55.

${ }^{97}$ Roger Edgeworth, Sermons very Fruitfull, Godly and Learned, ed. Janet Wilson (Cambridge: D. S. Brewer, 1993), 143.

${ }^{98}$ See R. W. Scribner, "Ritual and Reformation," in Popular Culture and Popular Movements in Reformation Germany (London: Hambledon, 1987), 114. A figure of the crucified Christ with his arms broken off dating from 1475-1525 discovered in an old mansion at Fiddleford, Dorset is now in the British Museum: 1998,0408.1. Joe Moshenska is currently working on this intriguing topic. For evidence of deliberate damage to surviving devotional figurines, see also David Gaimster, "Of 'Idols and Devils': Devotional Pipeclay Figurines from Southern Britain in their European Context," in Archäologie der Reformation: Studien zu den Auswirkungen des Konfessionswechsels auf die materielle Kultur, ed. Carola Jäggi and Jörn Staecker (Berlin: Walter de Gruyter, 2007): 269.
} 
Reformation created unprecedented opportunities for embezzlement, alienation, and theft. This is well-documented in the case of the dissolution of the monasteries. In his manuscript tract lamenting "the Fall of the Religious Houses" written about 1593, Michael Sherbrooke records the reply given by his father when asked why he had participated in dismantling Roche Abbey in Yorkshire despite his continued respect for the monasteries and their inhabitants: "What should I do, said He: might not I as well as others have some Profitt of ye Spoil . . . ? For I did see all would away; \& therefore I did as others did." 99 The apparent epidemic of unscrupulous looting and fraudulent acquisition of church goods that ensued explains why the Edwardian regime felt the need to draw up inventories in the first place and to prosecute those who absconded with ecclesiastical property. Joan Conquest from Bedfordshire was relentlessly pursued regarding the chalices, crimson velvet cope, white damask vestments, and other items that her husband had appropriated from the church of Houghton Conquest before his death. ${ }^{100}$ Churchwardens themselves were also suspected of stealing and the episcopal articles of Bishop Bickley of Chichester issued in 1586 asked if they wasted or spoiled any church goods. ${ }^{101}$ In the passage quoted at the start of this essay, Fuller described a process of appropriation of liturgical furnishings in which much of Tudor England was apparently complicit: "If first laying of hands upon them were sufficient title unto them, seizing on them was generally the price they had payed for them." Much of this activity evidently went undetected, "so cunningly they carried their stealths, seeing every one who had nimmed [pinched] a Church Bell, did not ring it out for all to hear the sound thereof." 102

Were those who eagerly participated in the great sale of the sixteenth century acting from mercenary motives? Were they conservatives anxious to rescue and protect the threatened patrimony of the Catholic Church in the hope that it might one day be restored to glory? Or were they avid evangelicals carrying through their convictions by desacralizing idolatrous objects by putting them to profane use? In the case of William Whittingham, the Bible translator, former Marian exile, and Elizabethan dean of Durham, who removed several holy water stones from the cathedral into his kitchen to deploy as containers for steeping beef and salt fish, it is probably safe to surmise that latter is

\footnotetext{
${ }^{99}$ Additional MS 5813, fos 20v-21r, British Library, printed in Michael Sherbrook, "The Fall of Religious Houses," in Tudor Treatises, ed. A. G. Dickens, Yorkshire Archaeological Society 125 (Leeds: Yorkshire Archaeological Society, 1959), 125.

${ }^{100} \mathrm{~F}$. C. Eeles and J. E. Brown, eds., The Edwardian Inventories for Bedfordshire, Alcuin Club Collections 6 (London: Longmans, Green, 1905), 24, 28.

${ }^{101}$ Kennedy, Elizabethan Episcopal Administration, 3:218. See also Dymond and Paine, Spoil of Melford Church, 32.

${ }^{102}$ Fuller, Church-history of Britain, 417, 419.
} 
true. After he died, his wife Katherine transferred one of these vessels to the buttery where it served as a basin in which to wash pots, plates, and cups: she was a defiant iconoclast in her own right, who had ostentatiously burnt the holy banner of renowned northern saint Cuthbert "in notable contempt \& disgrace."103

On other occasions, such activities seem to have been forms of pious theft or circumspect purchase designed to forestall the confiscation and destruction of hallowed objects that had been bequeathed by family members. In Long Melford, William Clopton of Kentwell Hall bought far more redundant church goods than anyone else, many of them linked with the chapel and chantry endowed by his ancestors, including a beautiful alabaster plaque depicting the Virgin and child in bed that was rediscovered under the floor in the Victorian period. ${ }^{104}$ The concealment of sacred things in houses and barns and the walling up of statues and stone crosses in churches have been evocatively described by Sarah Tarlow as forms of dissimulation and as elements of a subtle "archaeology of resistance."105 Many of those who removed mass books and vestments seem to have returned them when Mary ascended the throne. When Elizabeth succeeded her just five years later, they smuggled them out of churches into hiding once more. A cope borrowed by the parish of Ashby in Lincolnshire from Mrs. Stringer of Derby was given back to her in $1558 .{ }^{106}$ Church officials came to see such behavior as typical of church papists who were patiently "waiting for the day" when Rome would reign once more. Recusants were certainly responsible for preserving some spectacular examples of the school of ecclesiastical embroidery known as Opus Anglicanum. ${ }^{107}$

All too frequently, though, it is impossible to make windows into the souls of individuals such as the Lincolnshire yeoman and freeholder William Thixton who bought an altar stone from his parish church and "caused yt to be laide on his grave when he departed." Thixton may have been a devout Catholic anxious to be buried in close proximity to this most holy of objects, like the member of the Morley family whose remains are interred beneath the altar stone of the Holme chantry in Bottesford church, Leicestershire. But it is equally possible that he simply took advantage of the chance to acquire a

\footnotetext{
${ }^{103}$ J. T. Fowler, ed., Rites of Durham. Being a Description or Brief Declaration of all the Ancient Monuments, Rites, and Customs Belonging or being within the Monastical Church of Durham before the Suppression, Surtees Society 107 (Durham: Andrews and Co., 1903), 60-61, 26-27.

${ }^{104}$ Dymond and Paine, Spoil of Long Melford Church, 39; and Duffy, Stripping of the Altars, 490.

${ }^{105}$ Tarlow, "Reformation and Transformation," 118.

${ }^{106}$ Peacock, English Church Furniture, 30.

${ }^{107}$ This probably explains the survival of some of the items described in Browne, Davies, and Michael, English Medieval Embroidery, see 181, 249-251, 263.
} 
suitable piece of marble to make into a funeral monument intended to instruct spectators rather than prompt them to pray for his soul. ${ }^{108}$

The problem of interpretation is compounded by the fact that the processes of metamorphosis to which the Edwardian and Elizabethan inventories attest were not initiated by the Reformation. Together with the practice of pawning or selling valuables to raise funds, they were part of an economy of makeshifts that had many precedents and much deeper roots. ${ }^{109}$ Such strategies had long been deployed to solve cash flow problems, to meet emergency costs, and to pay for regular maintenance and necessary repairs to the church fabric and to parish amenities such as highways and dykes. ${ }^{110}$ Requiring the purchase of Bibles and prayer books and expenditure on the whitewashing of walls and painting of scripture texts, the transition to Protestantism was not inexpensive. In a climate of financial exigency, it was a fillip to recycling and to the trade in used goods. It provided both a fresh incentive and a powerful justification for converting liturgical items into ready money to fund civic works and to support the poor. In response to the interrogatories issued in 1552, many parishes reported that chalices, pyxes, and patens had been sold off to fund relief of those in need. In the Norfolk village of Saxthorpe, most of the money raised by the sale of plate, a suit of blue velvet, and a red cope was used to defray the cost of changes to the church interior and "other necessary things" ordered by the king's injunctions, but it also paid for the transportation of a local leper to Norwich and left a residue that was placed in the poor box. In Heydon, some of the proceeds of a similar sale were bestowed on a lame woman. ${ }^{111}$ Whatever drove the initiatives of the churchwardens and parishioners who made these returns, they were consistent with reformed priorities and thus likely to satisfy the commissioners. And while items of this kind regularly moved back and forth across the boundary between the sacred and profane, ${ }^{112}$ the

\footnotetext{
${ }^{108}$ Peacock, English Church Furniture, 121. For another example of an altar stone "laid for a grave stonne," see 112 .

${ }^{109}$ The phrase is more widely employed in relation to the poor. It was first coined by Olwen Hufton in The Poor of Eighteenth-Century France 1750-1789 (Oxford: Clarendon, 1974) and has become a powerful paradigm for scholars in this field. See, for example, Stephen King and Alannah Tomkins, eds., The Poor in England 1700-1850: An Economy of Makeshifts (Manchester: Manchester University Press, 2003).

${ }^{110}$ As noted by Duffy, Stripping of the Altars, 483 . Forthcoming work by Lucy Kaufman also tackles this theme.

${ }^{111}$ H. B. Walters, "Inventories of Norfolk Church Goods (1552)," Norfolk Archaeology 27 (1941): 410-411, 405 respectively.

${ }^{112} \mathrm{~A}$ revealing example is the diaper tablecloth Anne Heckford bequeathed to be cut into two to make covers for the communion tables at Saint Botolph and Holy Trinity, Colchester: F. G. Emmison, ed., Essex Wills: The Bishop of London's Commissary Court 1587-1599, (Chelmsford: Essex Record Office, 1998), 130.
} 
advent of Protestantism decisively tipped the balance of traffic toward the latter and invested it with ideological urgency.

Historians have disagreed about how to interpret the actions of the parish officials and private individuals who were implicated in such transactions. Eamon Duffy rejects the suggestion that they provide evidence of compliance, let alone enthusiasm, for reform, seeing them instead as examples of dutiful and enforced conformity to an unwelcome Reformation. ${ }^{113}$ For Ethan Shagan, by contrast, they yield insight into the manner in which ordinary people became "de facto collaborators with the regime's spiritual programme." As a consequence, they were obliged to forge "new consciences to navigate the unprecedented circumstances in which they found themselves." "114 My aim here is not to adjudicate in this debate. What I wish to highlight instead is the manner in which these developments overlaid material objects with fresh layers of meaning. The physical transfigurations they underwent were emblematic of fundamental shifts in memory culture itself: from remembrance as intercession and prayer to remembrance as recollection. ${ }^{115}$

However comprehensively they were defaced or altered in appearance, recycled objects continued to carry forward the experience of previous generations and recall a time before Protestantism had officially banished popery from the land. They had a double-edged quality: if they prompted the godly to celebrate their success in conquering superstition and idolatry, they also provided a focus for Catholic dissent and for the ongoing dream that England would return to faithful obedience to the Mother Church of Rome. The original and translated meanings of former sacred objects coexisted in uneasy equilibrium. A stimulus to both forgetting and remembering, they left a complex and divisive legacy that continued to destabilize the English nation for more than a century.

\section{Spoliation AND SACRILEge}

The final section of this essay investigates a different cluster of evidence regarding the afterlife of Catholic materiality, the process of recycling, and the reconfiguration of cultural memory. This is the rise, in the course of the later sixteenth and seventeenth centuries, of contemporary anxiety about the

\footnotetext{
${ }^{113}$ Duffy, Stripping of the Altars, chap. 14; and Duffy, "The End of it All," esp. 116-118.

${ }^{114}$ Shagan, Popular Politics, 287, 309.

${ }^{115}$ See Eamon Duffy, Reformation Divided: Catholics, Protestants and the Conversion of England (London: Bloomsbury, 2017), 186-187. For other helpful discussions, see Marshall, Beliefs and the Dead, chap. 7; Peter Sherlock, Monuments and Memory in Early Modern England (Aldershot: Ashgate, 2008), chap. 8; and Sherlock, "The Reformation of Memory in Early Modern Europe," in Memory: Histories, Theories, Debates, ed. Susannah Radstone and Bill Schwarz (New York: Fordham University Press, 2010), 30-40.
} 
sins and crimes of sacrilege that had been committed by their Tudor forebears. The drive against idolatry had always been accompanied by the worry that it could tip over into the realm of profanation and provoke the wrath of God. The fine line between acceptable use and perverted abuse of holy things was easy to breach. In this sense, Protestantism was caught between a rock and a hard place. And as time progressed, these tensions became increasingly stretched.

The precept that sanctified things should not be deputed to profane use was deeply embedded in medieval Catholicism. ${ }^{116}$ From the beginning, those who resisted the Reformation lambasted the excessive zeal of the heretics against Christian materiality and alighted self-righteously on examples of individuals who had been supernaturally punished for polluting and violating hallowed items that had once served liturgical functions and were now deployed for secular purposes. They were fond of predicting the disasters that the recycling of church buildings and goods would draw down on the heads of those who had taken advantage of the mass privatization of ecclesiastical land and furnishings in the mid-sixteenth century. Noticing the tombstones that had been laid in the courtyard as paving slabs, an "olde man with comly gray hayres," who came to beg alms at the former home of the redoubtable Catherine Whittingham in the North Bailey in Durham, declared that "nothing would prosper about the howse." This prophecy hung so heavily on the owner, one John Richardson, that after several of his children and others died, he moved them back into the abbey yard. ${ }^{117}$ The conversion of consecrated objects to alternative uses evidently often came back to haunt the heirs of those who had benefited from the Henrician and Edwardian Reformations.

Remembering the mishaps which befell those who committed such acts of profanation was itself a mode of resistance to this religious revolution. Outraged by the recycling of altar stones for municipal and agricultural purposes, the recusant Thomas Meynell recorded one such punitive miracle among his personal papers: the story of a Protestant whose horses refused to draw a cart containing a font he had confiscated from the chapel at Thornton le Beans and "for many yeares sacriligiously profained it, even to the very use of serving Hogs therein." ${ }^{118}$ The early seventeenth-century Cornish gentleman Nicholas Roscarrock's voluminous manuscript Alphebit of Saints included the case of a gentlewoman called Mistress Borlase who had carried off the hallowed stone at

\footnotetext{
${ }^{116}$ See, for example, William Lyndwood, Constitutions Provincialles, and of Otho, and Octhobone (London, 1534), 6.

${ }^{117}$ Fowler, Rites of Durham, 61-62.

118“"The Recusancy Papers of the Meynell Family of North Kilvington, North Riding of Yorkshire, 1596-1676," ed. J. C. H. Aveling, in Miscellanea, ed. E. E. Reynolds, Catholic Record Society 56 (London: Catholic Record Society, 1956), 40-41.
} 
East Newlyn on which Saint Nectan's relics had been displayed and reused it as a cheese press, but which was carried back to the churchyard after her death under cover of night, either on her direct instructions or by "some thinge assuming her personage"- in other words, by a ghost. ${ }^{119}$

The pangs of conscience experienced by those who physically demolished monasteries or converted them into domestic residences after 1538 are another measure of the ambiguous legacies of the Reformation in the realm of memory. At Titchfield in Hertfordshire, a carpenter evidently ceased his labor in "taking down the Churche of the Abbey" for fear that the hand of God might fall upon him. The wife of Thomas Wriothesley, who acquired this site, also seems to have been troubled on this account. A letter from the commissioners for the dissolution, John Crayford and Ronald Lathom, suggested that she and her husband should "neither be ... metticulous ne scrupulous to make sale of such holly thinge having ensample of a goode devoute bisshope of Rome called Alexander [VI] whos epitaph ys write after this sort: vendit Alexander cruces altaria Christi vendere jure potest/emerat illius prius" (Alexander sells the crosses and altars of Christ. He has the right to sell- he bought them first himself!). ${ }^{120}$ This scurrilous joke about a Renaissance pope infamous for his simony probably did little to assuage her worries about the possible consequences of inhabiting former religious houses and redeploying holy objects.

If anything, the passing of the generations directly implicated in the tumultuous events of the mid-sixteenth century intensified the lingering sense of unease about infringing this ancient taboo. ${ }^{121}$ Whereas earlier Protestants had equated the idolatrous misuse of material things with sacrilege, some later members of the Church of England turned the relationship between these concepts on its head, castigating the iconoclastic fervor of their forebears as itself a deplorable violation of the sacred. Everard Digby's Dissuasive from taking away the lyvings and goods of the Church (1590) was one sign of the times: alongside the "great blessings" poured out on those who had made generous benefactions to repair and maintain God's holy temples, he cited the judgement that befell King Balthasar in the Old

\footnotetext{
${ }^{119}$ Additional MS 3041, fol. 323v, Cambridge University Library, Cambridge, printed in Nicholas Roscarrock's Lives of the Saints: Cornwall and Devon, ed. Nicholas Orme, Devon, and Cornwall Record Society, n.s., 35 (Exeter: Devon and Cornwall Record Society, 1992), 78-79.

${ }^{120}$ Cited in Doggett, Patterns of Re-use, 56. See also W. H. St. John Hope, "The Making of Place House at Titchfield, near Southampton in 1538," Archaeological Journal 63 (1906): 235. I am grateful to Euan Cameron for pointing out the irony that the source of this quotation was a satirical pasquil attributed to Giovanni Pico della Mirandola.

${ }^{121}$ On sacrilege, see Keith Thomas, Religion and the Decline of Magic (Harmondsworth: Penguin, 1973), 112-121; Alexandra Walsham, The Reformation of the Landscape: Religion, Identity, and Memory in Early Modern Britain and Ireland (Oxford: Oxford University Press, 2011), 283-296; and Michael Kelly, "The Invasion of Things Sacred: Church, Property and Sacrilege in Early Modern England,” (PhD diss., University of Notre Dame, 2013).
} 
Testament book of Daniel who translated sacred vessels appointed for holy sacrifice to the Lord to profane use as part of his denunciation of various forms of church robbery. ${ }^{122}$ In the course of three sermons published in 1599, John Pont condemned the "Idole of sacrilegious avarice" that had taken root since "the first reformation of Religion amongst us" and extended it to those who had taken bells, ornaments, jewelery, timber, and stone and sold them for private gain rather than bestowed the money on ecclesiastical causes or on succoring the poor. Those who made profit by "spoyling the kirk," he thundered, all too often found that their houses were "nothing enriched, but rather damnified therby. For there followeth such a curse, \& secret mishap upon that kinde of fraith, that when even for necessarye causes, it is applyed to profane uses, oftentimes, it neither profiteth them that give it, nor that receve it." It was well-known, he said, that "a greate parte" of the lead plundered from churches and monasteries and shipped overseas had "perished by Sea" and proved of "little advantage to them who medled therewith." 123 By the turn of the seventeenth century, the idea that early Protestant recycling of the sacred had provoked divine indignation seems to have been deeply rooted in social memory.

Such sentiments coincided with the concerns expressed by avant garde conformists such as the Flemish divine Adrian Saravia, who encouraged his English colleagues to recall the calamities that had overtaken Germany and the Low Countries, which he saw as the "just vengeance of God" for the sacrileges committed by the Calvinists during the Reformation and the Dutch Revolt. ${ }^{124}$ Churchmen such as Lancelot Andrewes were beginning to think that the price paid for the purification of churches in the sixteenth century had been too high: the state of dilapidation in which they now stood was a scandal. It had helped to breed a contempt for sacred things that too many used to cover up their brazen acquisitiveness. ${ }^{125}$ John Whitgift's 1597 articles for Shoreham Deanery, which asked for the names of those who had pulled down the church, chancel, or chapels and removed bells and fonts from their accustomed places, hints at a subtle shift in the climate of opinion. ${ }^{126}$ Whereas earlier Elizabethan bishops had targeted recalcitrant parishes that had delayed getting rid of "monuments of popish superstition,"

\footnotetext{
${ }^{122}$ Everard Digby, Euerard Digbie his Dissuasiue from Taking away the Lyvings and Goods of the Church (London, 1590), 143-144.

${ }^{123}$ Robert Pont, Against Sacrilege, Three Sermons (Edinburgh, 1599), sigs. A4r, B6r, B8r-v.

${ }^{124}$ Adrian Saravia 1. Of the Diverse Degrees of the Ministers of the Gospel. 2. Of the Honor which is due unto the Priestes and Prelates of the Church. 3. Of Sacrilege, and the Punishment Thereof (London, 1591), 219-220.

${ }^{125}$ See Lancelot Andrewes's posthumously published Sacrilege a Snare: A Sermon Preached ad Clerum (London, 1646).

${ }^{126}$ Kennedy, Elizabethan Episcopal Administration, 3:292. See also Bancroft's articles for 1601, $3: 342$.
} 
Whitgift's inquiry was implicitly directed against those who displayed excessive iconoclastic zeal. It was a straw in the wind.

In the decades that followed, memory of medieval Catholicism itself began to mellow. In some circles within the Church of England, the break with Rome was increasingly perceived less as a frenzied flight from Babylon than as a reluctant divorce from a legitimate church that, though flawed with error, was not an anti-Christian one. ${ }^{127}$ The desire of the Laudians, who rose to power in the $1630 \mathrm{~s}$, to restore the beauty of holiness proved even more conducive to a rising tide of discourse about the dangers of profanation. Although the arguments of Edward Brouckner's Curse of sacrilege of 1630 were largely directed against the siphoning off of church revenue and tithes, his claim that "Hee is a theefe who meddles with holie things" applied more widely. ${ }^{128}$ They fed a growing impression that the dissolutions of the monasteries and chantries and the spoliation of parish churches had been driven chiefly by greed and that acts of violation carried out in the name of pretended "reformation" stank in the nostrils of God.

Nowhere was this growing ambivalence about the events of the recent past given more influential expression than in Henry Spelman's famous book on the history and fate of sacrilege, belatedly published in 1697, which set out to demonstrate that the Lord punished offenders down to the third and fourth generation. A ringing indictment of this "master sin" throughout the ages, but particularly during and since the dissolution, it was accompanied by an account of the disasters that had befallen the families of those who had purchased former religious houses, as well as Henry VIII and his posterity. Tellingly, it also contained chapters on the sacrilege of material things that compared more recent outrages with the theft of the Babylonian garment by Achan described in Joshua 7. Drawing on his own experience as a child in Norfolk, Spelman devoted a section to the divine judgements meted out to those who had stolen bells. He recalled that talk of these events was then "common in memory" and that "the sum of the speech usually" was that illgotten goods never prospered. Packed up to transport to Europe, they were often sunk in havens and harbors before they left these shores, while those who had embezzled or bought and sold them were stricken with blindness or died without issue. ${ }^{129}$ Such traditions attest to the role that material culture

\footnotetext{
${ }^{127}$ Anthony Milton, Catholic and Reformed: The Roman and Protestant Churches in English Protestant Thought, 1600-1640 (Cambridge: Cambridge University Press, 1995), pt. 1.

${ }^{128}$ Edward Brouckner, The Curse of Sacrilege Preached in a Private Parish Church (London, 1630), 16.

${ }^{129}$ Henry Spelman, The History and Fate of Sacrilege, Discover'd by Examples of Scripture, of Heathens, and of Christians; from the Beginning of the World Continually to this Day (London, 1698), 5. Section 7 is devoted to "Sacrilege of materials or things." For the divine judgements on bell thieves, see $285-287$.
} 
played in evoking counter memories of the Reformation - memories at odds with officially forged narratives that celebrated the dissolution of the monasteries and the purging of parish churches as components of a righteous crusade against the soul-destroying sin of idolatry and against institutions that embodied false doctrine and condoned sordid vice. ${ }^{130}$

Reports and rumors about similar providential judgements continued to circulate orally and to find their way into antiquarian collections that tried to preserve a permanent record of a material past that seemed to be rapidly evaporating. The late seventeenth-century Yorkshire antiquary Abraham de le Pryme collected several tales of the misfortunes suffered by those who had reused monastic stone, which he saw as indictments of the "sad havok that was made of religious things in the time of the Reformation." These included the story of the fen drainers who had built Ferriby Sluice in Linconshire from the stone of a chapel associated with Thornton Priory: "For applying that to profane uses that had been given to God," he recorded, they were all undone, and their expensive engineering work was "now coming down." 131 Sir Henry Chauncy's Historical Antiquities of Hertfordshire of 1700 recorded the case of Sir Leonard Hide, whose estate had "suddenly wasted" and whose name had become "extinguisht" after he paved his kitchen with gravestones taken from Throcking parish church and fraudulently embezzled some of the glebe land. ${ }^{132}$ Bearing witness to the burden of guilt bequeathed by the Reformation, such episodes also attest to the extent to which recycled sacred objects remained mnemonics to older beliefs and assumptions. Ambiguous and polyvalent, they continued to provide tangible foci and touchstones for remembering a past that, despite Protestantism's best efforts, refused to be cast into oblivion.

By the later seventeenth and early eighteenth centuries, then, the transactions documented in Edwardian and Elizabethan inventories and churchwardens' accounts and in episcopal visitation articles were becoming less a source of celebration and pride than of embarrassment and anxiety. Following Eamon Duffy, it may be commented that the catalogues compiled in 1552 served to encode "a memory of now outlawed pieties." ${ }^{133}$ Listing the items that would shortly be confiscated and destroyed or put to profane use in circumstantial

\footnotetext{
${ }^{130}$ See Andy Wood, The Memory of the People: Custom and Popular Senses of the Past in Early Modern England (Cambridge: Cambridge University Press, 2013), chap. 1; and Lyon, "The Afterlives of the Dissolution."

${ }^{131}$ Charles Jackson, ed., The Diary of Abraham de la Pryme, the Yorkshire Antiquary, Surtees Society, 54 (Durham: Surtees Society, 1870), 309, 131, see also 226. For other judgements on those who committed the sin of sacrilege, see 145, 159, 174.

${ }^{132}$ Sir Henry Chauncy, The Historical Antiquities of Hertfordshire (London, 1700), 117. Chauncy hoped that he had not committed so heinous a crime but could only confirm his impoverishment and lack of issue.

${ }^{133}$ Duffy, "End of it All," 121.
} 
detail, they helped to keep a record of the material world of medieval Catholicism. And they may even have assisted in stimulating nostalgia for its loss. Interestingly, conservative and recusant attempts to preserve on paper also took the form of descriptive catalogues. Texts such as Roger Martyn's poignant account of Long Melford and the "Rites of Durham" (written by William Claxton around 1593) enumerated and lovingly reimagined rituals and objects that were in danger of passing from living memory into oblivion. In highlighting the absence of once present physical objects, they ensured their remembrance. ${ }^{134}$ In both generic form and tone, a line can be drawn between these memorializing works and John Weever's Ancient Funeral Monuments (1631) and William Dugdale's Monasticon Anglicanum and History of St. Paul's Cathedral. ${ }^{135}$

The distaste for "barbarous" and misdirected evangelical zeal that runs through these books also pervades many of the nineteenth- and early twentieth-century editions of the bureaucratic texts that have been the primary sources for this essay. These too are tinted with regret for the "extreme puritanism" that had infected English Protestantism from the Continent and for the renewed "fanatic fury," "malevolence," and "bigotry" that marked the "Great Rebellion." They too lament the extent to which parish churches were "left clad in the rags of humiliation" and label the forms of object conversion I have analyzed above as "desecrations."136 The impulses that drove their editors to transcribe, annotate, and reproduce them may be seen as a continuation of the pressing desire to save the material heritage of medieval Christianity that drove the endeavors of many sixteenth- and seventeenth-century antiquarians. They were products of a movement that gave rise to a new myth of the English Reformation that occluded its early radicalism and played up its intrinsic moderation. ${ }^{137}$

\footnotetext{
${ }^{134}$ Roger Martyn's account is reproduced in Sir William Parker, The History of Long Melford (London, 1873), 70-74; and Fowler, Rites of Durham. See Jones, Memory and Material Culture, 39.

${ }^{135}$ John Weever, Ancient Funerall Monuments within the United Monarchie of Great Britaine, Ireland, and the Islands Adjacent, with the Dissolved Monasteries therein Contained (London, 1631); Roger Dodsworth and William Dugdale, Monasticon Anglicanum sive Pandectce Conobiorum, Benedictinorum Cluniacensium, Cisterciensium, Carthusianorum; a primordiis ad eorum usque dissolutionem, 3 vols. (London, 1655-1673); and William Dugdale, The History of St. Pauls Cathedral in London (London, 1658).

${ }^{136}$ Eeles and Brown, Edwardian Inventories for Buckinghamshire, xlix; Nightingale, Church Plate of the County of Dorset, 80; and Cresswell, Edwardian Inventories for the City and County of Exeter, xvi. See also Cox and Harvey, English Church Furniture, 34.

${ }^{137}$ Diarmaid MacCulloch, "The Myth of the English Reformation," Journal of British Studies 30 (January 1991): 1-19.
} 


\section{CONCLUSION}

This article has investigated the biographies and afterlives of religious objects that survived the successive phases of the English Reformation. It has traced how material artifacts that Protestants regarded as superstitious and idolatrous evaded destruction by undergoing forms of physical adaptation that rendered them fit for other civil and ecclesiastical uses. While this was sometimes a strategy of dissimulation or a product of pragmatism, it was also a studied technique of desacralization that had a haptic dimension. It embodied the theological precept that things were in themselves indifferent and could therefore legitimately be converted to other purposes, subject to considerations of edification and scandal. The difficulties involved in drawing a line between idolatry and sacrilege stirred up trouble that contributed toward undermining the unity of the embryonic and maturing Church of England.

Relocated into new arenas, including the home, such objects afford further insight into what John Bossy influentially described as the "migrations of the holy." 138 These translations overlaid preexisting meanings with new layers of significance without ever completely effacing old ones. Stripped of their roles in a medieval culture of salvific remembrance and imported into a new Protestant world that had dispensed with purgatory, they nevertheless remained vehicles and nodes of memory. They preserved a link with the past that helped English society to adjust to the shock of the rupture wrought by the religious revolution and to build new symbols of attachment, even as it ensured that Catholic Christianity remained latent in the imagination. The trajectories and journeys undertaken by church furniture offer fresh insight into the material and cultural impact of Protestantism in early modern England. Recycling - or, to use the contemporary term, conversion - turns out to be a very apt metaphor for the physical and spiritual transformations that occurred in the wake of the Reformation.

\footnotetext{
${ }^{138}$ John Bossy, Christianity in the West 1400-1700 (Oxford: Oxford University Press, 1985), chap. 8 .
} 